\title{
Reversibility and safety of KISS1 metastasis suppressor gene vaccine in immunocastration of ram lambs
}

\author{
Yan-Guo Han ${ }^{1,2}$, Gui-Qiong Liu ${ }^{2, *}$, Xun-Ping Jiang ${ }^{2, *}$, Xing-Long Xiang ${ }^{2}$, Yong-Fu Huang ${ }^{1}$, Bin Nie ${ }^{2}$, \\ Jia-Yu Zhao ${ }^{2}$, ljaz Nabeel ${ }^{2}$, and Birhanu Tesema ${ }^{2}$
}

\author{
* Corresponding Authors: \\ Gui-Qiong Liu \\ Tel: +86-27-87585120, Fax: +86-27-87585120, \\ E-mail: liuguiqiong@mail.hzau.edu.cn \\ Xun-Ping Jiang \\ Tel: +86-27-87585120, Fax: +86-27-87585120, \\ E-mail: xpjiang@mail.hzau.edu.cn \\ ${ }^{1}$ Chongqing Key Laboratory of Forage \& Herbivore, \\ Chongqing Engineering Research Centre for \\ Herbivores Resource Protection and Utilization, \\ College of Animal Science and Technology, Southwest \\ University, Chongqing 400715, China \\ ${ }^{2}$ Key Laboratory of Agricultural Animal Genetics, \\ Breeding and Reproduction of the Ministry \\ of Education, College of Animal Science and \\ Technology, Huazhong Agricultural University, Wuhan \\ 430070, China \\ ORCID \\ Yan-Guo Han \\ https://orcid.org/0000-0002-0118-6666 \\ Gui-Qiong Liu \\ https://orcid.org/0000-0003-3688-5958 \\ Xun-Ping Jiang \\ https://orcid.org/0000-0001-7822-1784 \\ Xing-Long Xiang \\ https://orcid.org/0000-0002-6345-9164 \\ Yong-Fu Huang \\ https://orcid.org/0000-0001-9394-6169 \\ Bin Nie \\ https://orcid.org/0000-0001-8886-9779 \\ Jia-Yu Zhao \\ https://orcid.org/000-0002-9540-0714 \\ ljaz Nabeel \\ https://orcid.org/0000-0002-0732-4046 \\ Birhanu Tesema \\ https://orcid.org/0000-0003-0852-1962
}

Submitted Aug 23, 2017; Revised Nov 13, 2017; Accepted Dec 11, 2017
Objective: The aim of this study was to investigate the reversibility and safety of KISS1 metastasis suppressor (KISS1) gene vaccine in immunocastration.

Methods: Six eight-week old ram lambs were randomly divided into vaccinated and control groups. The vaccine ( $1 \mathrm{mg} / \mathrm{ram}$ lamb) was injected at weeks 0,3 , and 6 of the study. Blood samples were collected from the jugular vein before primary immunization and at weeks 2 , $4,6,10,14,22$, and 30 after primary immunization. All ram lambs were slaughtered at 38 weeks of age, and samples were collected.

Results: The specific anti-KISS1 antibody titers in vaccinated animals were significantly higher and the serum testosterone level was significantly lower than those in the control groups from week 4 to 14 after primary immunization $(\mathrm{p}<0.05)$. No significant difference was observed at weeks 22 and 30 after the primary immunization. Similar results were also found for scrotal circumference, testicular weight, length, breadth, and spermatogenesis in seminiferous tubules in week 30 after primary immunization. KS (KISS1-hepatitis B surface antigen $S$ ) fusion fragment of KISS1 gene vaccine was not detected in host cell genomic DNA of 9 tissues of the vaccinated ram lambs by polymerase chain reaction.

Conclusion: The effects of KISS1 gene vaccine in immunocastration were reversible and no integration events were recorded.

Keywords: KISS1 Metastasis Suppressor; Gene Vaccine; Immunocastration; Reversibility; Safety; Ram Lambs

\section{INTRODUCTION}

Vaccines against immunocastration can effectively suppress the reproductive function of farm animals [1,2], wild animals [3,4] and pets [5]. We aim to suppress temporarily reproductive function of wild and domestic animals during immunocastration and only restore reproductive ability only when necessary. Kisspeptins encoded by KISS1 metastasis suppressor (KISS1) gene are critical for the onset of puberty and the control of adult reproduction, which in turn controls secretion [6,7]. Our previous study demonstrated that KISS1 can be used as a novel target for developing a DNA immunocastration vaccine, wherein KISS1 gene vaccine can effectively suppress the gonadal function by immune-mediated neutralizing activities [8]. The reversibility and safety of KISS1 gene vaccine for immunocastration remains unclear.

The integration between this vaccine and host cell genomic DNA is an important security issue. Numerous studies showed that gene vaccines did not integrate into the genomic DNA of the host cell in vivo [9-11]; a few studies reported integration events in vitro [12,13]. Given this gap in research, the integration between KISS1 gene vaccine and the genomic 
DNA of the host cell should be evaluated to ensure its safety.

This study evaluates the reversibility of KISS1 gene vaccine for immunocastration in ram lambs in terms of changes in anti-KISS1 antibody titers, serum testosterone levels, scrotal circumference, testicle weight, and spermatogenesis in the seminiferous tubules. The safety of immunocastration against KISS1 gene vaccine was evaluated in terms of the integration of fusion gene KS (KISS1- HBsAg-S, HBsAg-S refers to hepatitis B surface antigen S) of KISS1 gene vaccine and genomic DNA of the host cell in vaccinated ram lambs.

\section{MATERIALS AND METHODS}

\section{Animals}

Six healthy male Hu sheep (Hengtai Sheep Breeding Co., Ltd, Hubei, Huanggang, China) aged eight weeks were treated based on the National Institutes of Health Guides for the Care and Use of Laboratory Animals. These ram lambs were randomly allocated into group $\mathrm{T}$ and group C (3 lambs each) based on comparable scrotal circumference, body weight and date of birth (Table 1). Group $\mathrm{T}$ was the vaccinated group and group $\mathrm{C}$ was the control group.

\section{Vaccination and sampling}

KISS1 gene vaccine $\mathrm{pKS}$-asd (asd refers to aspartate- $\beta$-semialdehyde dehydrogenase), an antibiotic-free recombinant plasmid encoding the human KISS1 gene which fused with $\mathrm{HBs} A g-\mathrm{S}$ gene, was successfully constructed in our laboratory [8]. Four milliliters of $0.25 \%$ lidocaine hydrochloride were intramuscularly injected in the quadriceps femoris of each ram lamb $24 \mathrm{~h}$ before immunization. Lambs in Group T were injected with $1 \mathrm{mg}$ pKS-asd whereas lambs in group $\mathrm{C}$ were treated with $1 \mathrm{mg}$ of pVAX-asd which is an empty vector without antibiotic resistance gene. All animals in both groups were boosted twice at an interval of three weeks. Blood samples were collected from the jugular vein before primary immunization (8 weeks of age) and at weeks $2,4,6,10,14,22$, and 30 after the primary immunization $(10,12,14,18,22,30$, and 38 weeks of age). Serum was collected after centrifugation at $1,157 \times \mathrm{g}$ at $4^{\circ} \mathrm{C}$ for $10 \mathrm{~min}$ and stored at $-20^{\circ} \mathrm{C}$ for further use.

Table 1. Scrotal circumference, body weight and date of birth in vaccinated (Group T) and control (Group C) ram lambs when ram lambs of 8-week-old were randomly grouped

\begin{tabular}{lccc}
\hline Group & \multicolumn{3}{c}{ Traits } \\
\cline { 2 - 4 } & $\begin{array}{c}\text { Scrotal } \\
\text { circumference }(\mathbf{c m})\end{array}$ & $\begin{array}{c}\text { Body weight } \\
(\mathbf{k g})\end{array}$ & $\begin{array}{c}\text { Date of birth } \\
(\mathrm{mm} / \mathrm{dd} / \mathrm{yyyy})\end{array}$ \\
\hline $\mathrm{T}$ & $11.27 \pm 0.68$ & $15.12 \pm 0.55$ & $11 / 13 / 2013$ \\
$\mathrm{C}$ & $11.34 \pm 0.76$ & $15.05 \pm 0.58$ & $11 / 13 / 2013$ \\
\hline
\end{tabular}

* There was no significant difference between vaccinated (Group T) and control (Group C) for all traits in this table.

\section{Detection of anti-KISS1 antibodies}

Specific anti-kisspeptin-54 antibodies were detected by an indirect enzyme-linked immunosorbent assay (ELISA) method [8]. This process was followed by brief coating of 96-well ELISA plates with $100 \mathrm{ng} /$ well of kisspeptin-54 diluted in a bicarbonate buffer $(\mathrm{pH} 9.6)$ overnight at $4^{\circ} \mathrm{C}$. The samples were then washed with phosphate buffer saline with $0.05 \%$ Tween-20 (PBST) and blocking with $1 \%$ bovine serum albumin at $37^{\circ} \mathrm{C}$ for $1 \mathrm{~h}$. Serum samples were serially 2-fold diluted in PBST from $1: 25$ up to $1: 1,600$, and then $100 \mu \mathrm{L}$ were added to the wells and were incubated at $37^{\circ} \mathrm{C}$ for $1 \mathrm{~h}$. Serum from a negative control from preimmune animals was also used. Bound antibodies were detected by adding horseradish peroxidaselabelled donkey anti-sheep IgG antibodies (Abbkine, Inc., Redlands, CA, USA) diluted 1/5,000 in PBST and incubated at $37^{\circ} \mathrm{C}$ for $1 \mathrm{~h}$. Enzyme reaction was developed with tetramethylbenzidine substrate by incubating the plate at $37^{\circ} \mathrm{C}$ for $10 \mathrm{~min}$. The reactions were stopped with $2 \mathrm{M} \mathrm{H}_{2} \mathrm{SO}_{4}$ and absorbance was determined at $450 \mathrm{~nm}$ in a plate reader (Bio-Rad iMark Microplate Absorbance Reader, Hercules, CA, USA). End-point titers were recorded as the reciprocal of the highest serum dilution, which yielded an absorbance greater than the mean plus two standard deviations of negative control samples at the same dilution $[14,15]$.

\section{Detection of serum testosterone concentrations}

Serum testosterone concentrations (STCs) were detected by ELISA method using commercial kits and performed according to instructions of the manufacturer (Cusabio Biotech., Wuhan, China). The intra-assay coefficient of variation was less than or equal to $15 \%$ and the inter-assay coefficient of variation was less than or equal to $15 \%$, respectively. Detection limit was $0.05 \mathrm{ng} / \mathrm{mL}$.

\section{In situ and ex situ of testicular size}

After pushing the testicles to the bottom of the scrotum, the scrotal circumference of ram lambs was determined with a flexible plastic measuring tape [16]. The paired testes, including epididymis, were weighed after the ram lambs were slaughtered at 38 weeks of age. Testicular breadth and length were thereafter determined using Vernier's caliper.

\section{Histological evaluation of reproductive organs}

The testes tissue samples of all animals were fixed with $10 \%$ (v/v) buffered neutral formalin and stained with Mayer's Haematoxylin and Eosin for histologic examination [17]. The diameter and circumference of seminiferous tubule for each animal was determined by measuring at least 15 tubules from multiple fields and averaging the values [18].

\section{Detection of integration of plasmid DNA into host genomic DNA}


These tissue samples, including hypothalamus, testis, heart, liver, lung, spleen, kidney, muscle and small intestine, were collected immediately after the ram lambs were slaughtered at 38 weeks of age and brought back to the laboratory at $4^{\circ} \mathrm{C}$. These tissue samples with 0.25 to $0.5 \mathrm{~g}$ were separately selected and cut up, then genome DNA was extracted by a classical phenol-chloroform extraction method [19]. Detection of integration of plasmid DNA into host genomic DNA by polymerase chain reaction (PCR). PCR sensitivity was also distinguished by detecting known amounts of pKS-asd [16]. Plasmid concentration of pKS-asd was adjusted to $49 \mathrm{ng} / \mu \mathrm{L}$ which approximately contained $10^{10}$ copies $/ \mu \mathrm{L}$, The plasmid was then serially diluted 10 -fold to $10^{-1}, 10^{-2}, 10^{-3}, 10^{-4}, 10^{-5}, 10^{-6}$, $10^{-7}, 10^{-8}, 10^{-9}, 10^{-10}$, which contained $10^{9}, 10^{8}, 10^{7}, 10^{6}, 10^{5}, 10^{4}$, $10^{3}, 10^{2}, 10^{1}, 10^{0}$ copies/ $\mu \mathrm{L}$, respectively. KS fusion gene $(840$ bp, sense of primers 5 -ATGGAGAACATCACATCAGGATT CCTAGGA-3', anti-sense of primers 5'-GAAGCGCAGGCCG AAGGAGT-3') from mixtures of $1 \mu \mathrm{L}$ diluted plasmid and 1 $\mu \mathrm{L}(1 \mu \mathrm{g} / \mu \mathrm{L})$ genomic DNA of control group lambs was amplified by PCR. KS fusion gene from genomic DNA $1 \mu \mathrm{L}(1$ $\mu \mathrm{g} / \mu \mathrm{L})$ of vaccinated ram lambs was amplified by PCR $[9,16]$. The PCR reaction was consisted of $25 \mu \mathrm{L}$ mix liquids containing $1 \mu \mathrm{L}$ of template DNA $(1 \mu \mathrm{g}), 0.5 \mu \mathrm{L}$ of Taq polymerase $(5 \mathrm{U} / \mu \mathrm{L}), 2 \mu \mathrm{L}$ dNTPs $(2.5 \mathrm{mmol} / \mathrm{L}), 1.0 \mathrm{~mL}$ of each primer (75 ng/ $\mu \mathrm{L}$ ), $17 \mu \mathrm{L}$ of $\mathrm{ddH}_{2} \mathrm{O}$, and $2.5 \mu \mathrm{L} 10 \times$ reaction buffer (with $20 \mathrm{mM} \mathrm{MgCl}_{2}$ ). The PCR programmed conditions included an initial incubation at $95^{\circ} \mathrm{C}$ for 5 mins followed by 3 -step cycling conditions for 35 cycles; $95^{\circ} \mathrm{C}$ denaturation for $30 \mathrm{~s}, 55^{\circ} \mathrm{C}$ annealing for $30 \mathrm{~s}, 72^{\circ} \mathrm{C}$ elongation for $20 \mathrm{~s}$, and a final cycle for $10 \mathrm{mins}$ at $72^{\circ} \mathrm{C}$. The PCR products were detected by electrophoresis with $1.2 \%$ polyacrylamide gel.

\section{Statistical analysis}

The differences between groups in terms of anti-KISS1 antibody titers, scrotal circumference, serum testosterone concentration, testis weight, testicular breadth, testicular length, tubule diameter, and circumference were analyzed by unpaired student's $t$-test of SAS 8.1 (SAS Institute, Inc., Cary, NC, USA). Less than $0.05 p$ value was considered statistically significant and data were expressed as mean \pm standard deviation.

\section{RESULTS}

\section{Anti-KISS1 antibody response, serum testosterone} level and scrotal circumference

KISS1-specific antibody titers in vaccinated lambs (Group T) were significantly higher than that in control animals from week 4 to 14 after primary immunization (Figure $1 \mathrm{~A}, \mathrm{p}<0.05$ ). However, no significant difference was observed in anti-KISS1 antibody titers between the two groups at weeks 22 and 30 after the primary immunization.
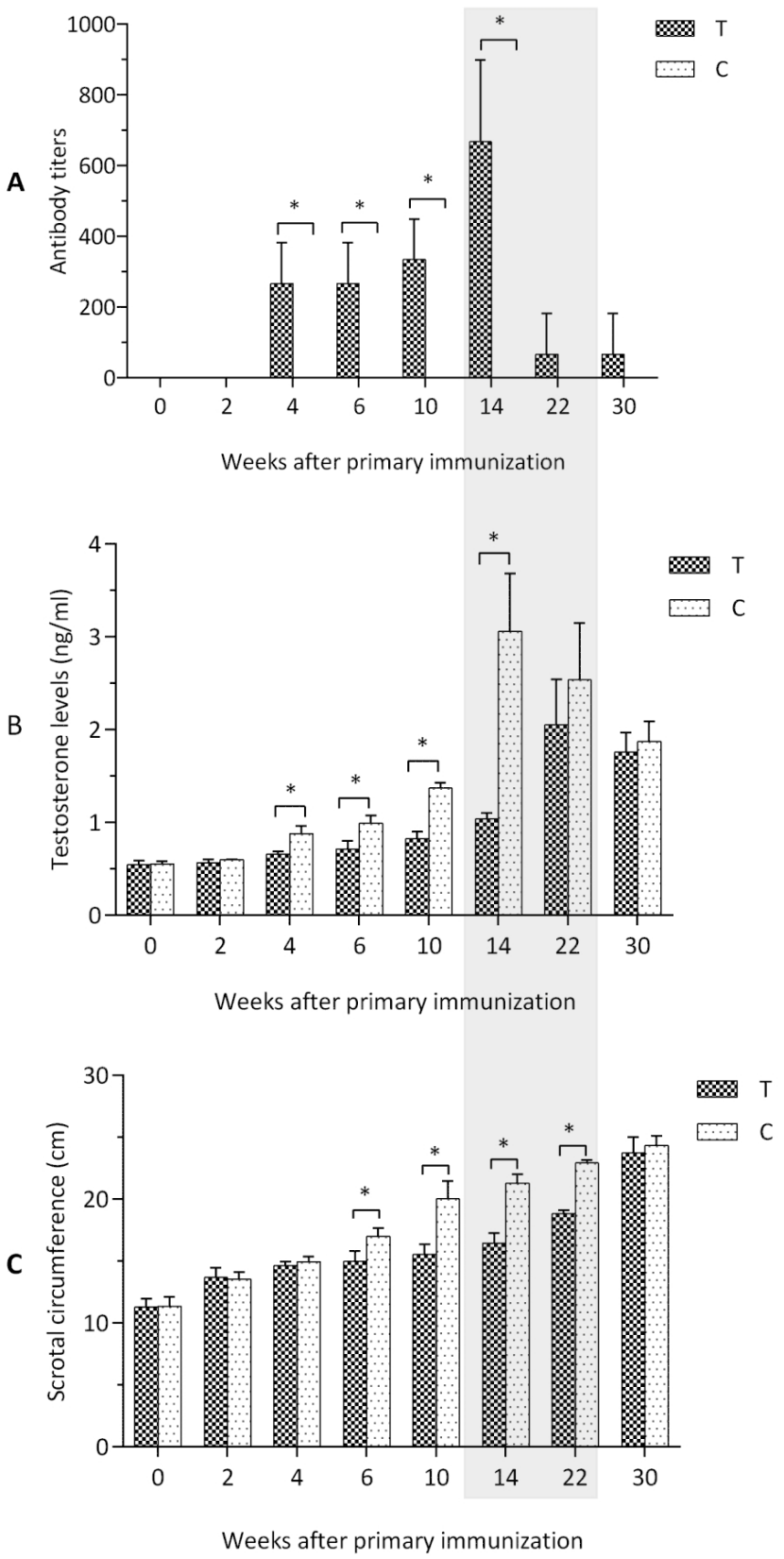

Figure 1. (A) Anti-KISS1 antibodies titers, (B) serum testosterone concentrations, and $(C)$ scrotal circumference in ram lambs immunized with pKS-asd (Group T) and pVAX-asd (Group C) at weeks 0, 2, 4, 6, 10, 14, 22, and 30 after the primary immunization. Vaccinations were respectively conducted at weeks 0,3 , and 6 weeks after primary immunization $(8,11$, and 14 weeks of age). Data are presented as means \pm standard deviation. ${ }^{*} p<0.05$.

STC in vaccinated lambs (Group T) were significantly lower than in control lambs (Group C) from week 4 to 14 after primary immunization (Figure $1 \mathrm{~B}, \mathrm{p}<0.05$ ). However, no significant difference was observed in testosterone concentrations between the two groups at weeks 22 and 30 after the primary immunization.

Scrotal circumference in vaccinated animals was significantly lower than in control animals at weeks 6, 10, 14, and 22 after 
the primary immunization (Figure $1 \mathrm{C}, \mathrm{p}<0.05$ ). No significant difference was observed in scrotal circumference between the two groups at week 30 after primary immunization.

\section{Weight of testes and microscopic evaluation}

No significant difference was observed in testicle weight, length and breadth between vaccinated and control group animals (Table 2; Figure 2Aa, $\mathrm{Ab}$ ) at week 30 after primary immunization.

The results of the microscopic examination showed no clear difference between the densities of spermatogonia type A, pri- mary spermatocytes at the pachytene stage, spermatids at the zygotene stage and spermatozoa in the seminiferous tubules of vaccinated (Figure 2Ba) and control lambs (Figure $2 \mathrm{Bb}$ ) at week 30 after the primary immunization. The normal process of spermatogenesis was evident in the seminiferous tubules of lambs in both groups (Figure 2B). No significant difference was observed in seminiferous tubule diameter and circumference between vaccinated and control group animals (Table 2) at week 30 after the primary immunization.

\section{Detection of integration of plasmid DNA into host}

Table 2. Testicle weight, length, breadth, seminiferous tubule diameter and circumference in vaccinated (Group T) and control (Group C) ram lambs at week 30 after primary immunization (age for 38 weeks)

\begin{tabular}{lccccc}
\hline Group & \multicolumn{5}{c}{ Traits } \\
\cline { 2 - 6 } & $\begin{array}{c}\text { Testicle weight } \\
(\mathbf{g})\end{array}$ & $\begin{array}{c}\text { Testicle length } \\
(\mathbf{c m})\end{array}$ & $\begin{array}{c}\text { Testicle breadth } \\
(\mathbf{c m})\end{array}$ & $\begin{array}{c}\text { Seminiferous tubule diameter } \\
(\boldsymbol{\mu m})\end{array}$ & $\begin{array}{c}\text { Seminiferous tubule circumference } \\
(\boldsymbol{\mu m})\end{array}$ \\
\hline $\mathrm{T}$ & $190.97 \pm 28.09$ & $6.52 \pm 0.12$ & $4.74 \pm 0.15$ & $205.05 \pm 14.21$ & $672.82 \pm 41.36$ \\
$\mathrm{C}$ & $207.70 \pm 28.23$ & $6.69 \pm 0.21$ & $4.78 \pm 0.54$ & $206.89 \pm 15.62$ & $677.07 \pm 44.05$ \\
\hline
\end{tabular}

* There was no significant difference between vaccinated (Group T) and control (Group C) for all traits in this table.
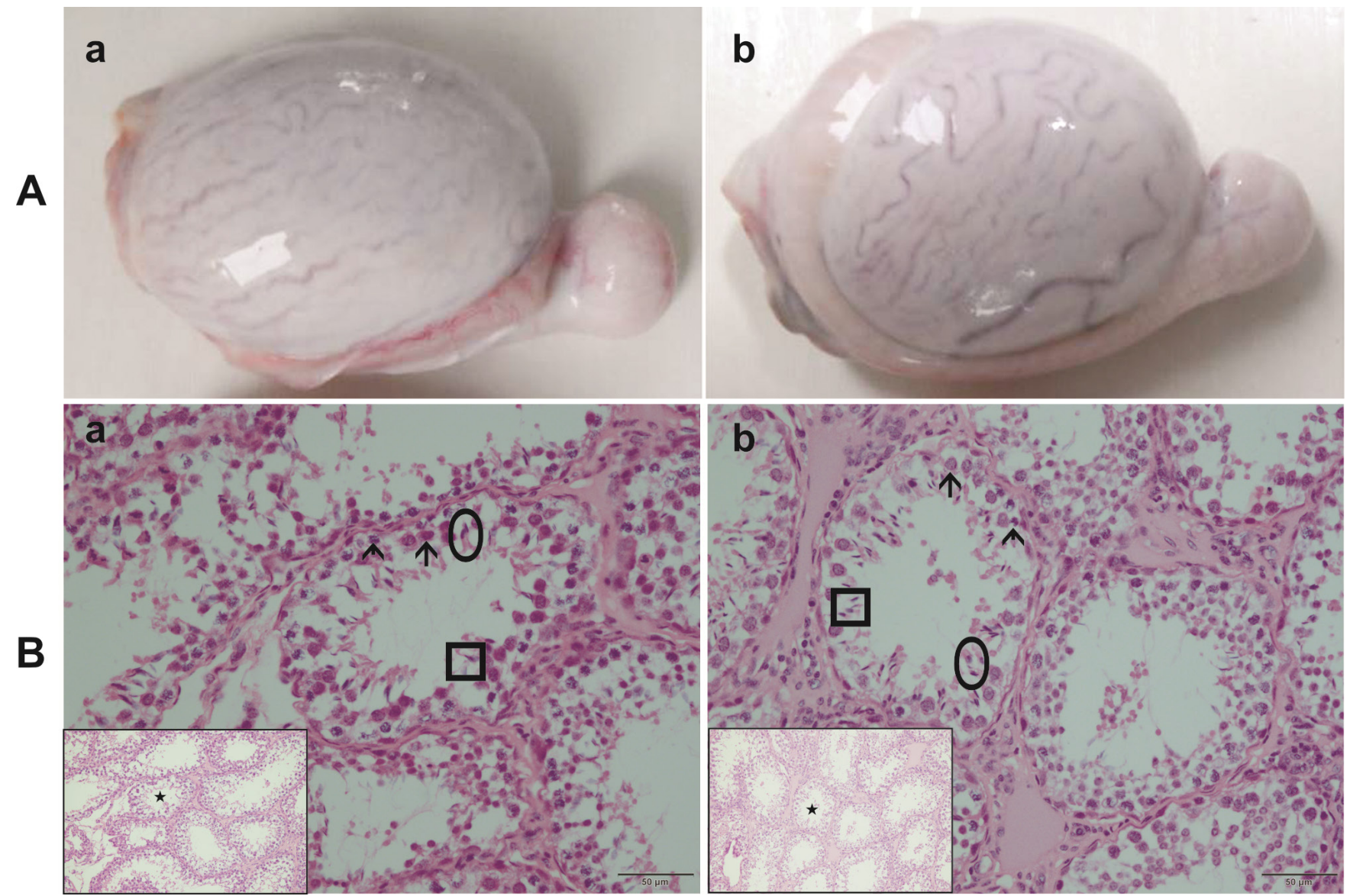

Figure 2. (A) Appearance and (B) microscopic evaluation of testis of ram lambs from ( $\mathrm{Aa}, \mathrm{Ba}$ ) treated and (Ab, $\mathrm{Bb}$ ) control groups at week 30 after the primary immunization (38 weeks of age). Photomicrographs of the cross-sections of seminiferous tubules represent the stages of spermatogenesis of seminiferous epithelium: spermatogonia type A (short arrows), primary spermatocytes at the pachytene stage (long arrows), spermatids at the zygotene stage (ellipse area) and spermatozoa (rectangular area). H\&E, scale bar $-50 \mu \mathrm{m}$ or $100 \mu \mathrm{m}$ (insets). 


\section{genomic DNA}

The sensitivity of PCR was approximately 10 copies of plasmid in $1 \mu \mathrm{g}$ genomic DNA (Figure 3A). No KS fusion fragments at this sensitivity level were noted in genomic DNA in the samples of nine different tissues obtained from vaccinated ram lambs (Figure 3B).

\section{DISCUSSION}

Immunocastration is an effective method for suppressing the reproduction of different animal species [20-22]. Gene vaccine is a superior method of immunocastration because of its lower costs than other synthetic peptide or protein vaccines. However, previous studies that used immunocastration gene vaccine are mainly focused on the effects of immunocastration $[8,17,23]$ with little information on the reversibility and safety of immunocastration gene vaccines.

The present study found that KISS1 gene immunocastration was reversible in ram lambs. Anti-KISS1 antibody response in the vaccinated group was detected in previous and current studies from week 4 to 14 after the primary immunization [8]. However, the anti-KISS1 antibody response in this study rapidly decreased at weeks 22 and 30 after the primary immunization. This finding resulted in a lack of significant difference in anti-KISS1 titers between the vaccinated and the control ram lambs. The rapid decrease of anti-KISS1 antibody response could be attributed to the shift of immune type from the predominant Th2 type (humoral immune response) to a Th1 type (cellular immune response) or a balance of Th1/Th2 type release [24-27]. A substantial amount of plasmid pKS-asd and antigens of endogenous synthesis can be cleared by macrophages because of increased cellular immune response. The immunization of ram lambs with KISS1 gene vaccine suppressed production of serum testosterone at weeks $4,6,10$, and 14 after primary immunization. This finding could have resulted in the suppression of scrotal circumference growth at week 6, 10, 14, and 22 after the primary immunization. Previous study also showed that the immunization of subject ram lambs with KISS1 gene vaccine suppressed the production of serum testosterone and scrotal circumference growth from week 4 to 14 and week 6 to 14 after the primary immunization, respectively [8]. However, slight suppression of production of serum testosterone in vaccinated group lambs was observed in the current study at weeks 22 and 30 after primary immunization. This finding could have resulted in slight suppression of scrotal circumference growth, testicular weight, length, breadth and spermatogenesis in seminiferous tubules at week 30 after the primary immunization. The testosterone level and scrotal circumference in control animals continued to increase until 14 weeks after the primary immunization and sharply dropped or slowly increased afterwards. This finding could be attributed to the age of animals, namely, the occurrence of puberty at 22 weeks of age. Our results showed that a KISS1antagonistic gene vaccine could produce high anti-KISS1 antibody response and suppress the production of serum testosterone thereby resulting in the suppression of growth and development of testis. However, the inhibition of KISS1-antagonistic gene vaccine on the growth and development of testis gradually disappeared with the decline of anti-KISS1 antibody titers and recovery of serum testosterone. The gray

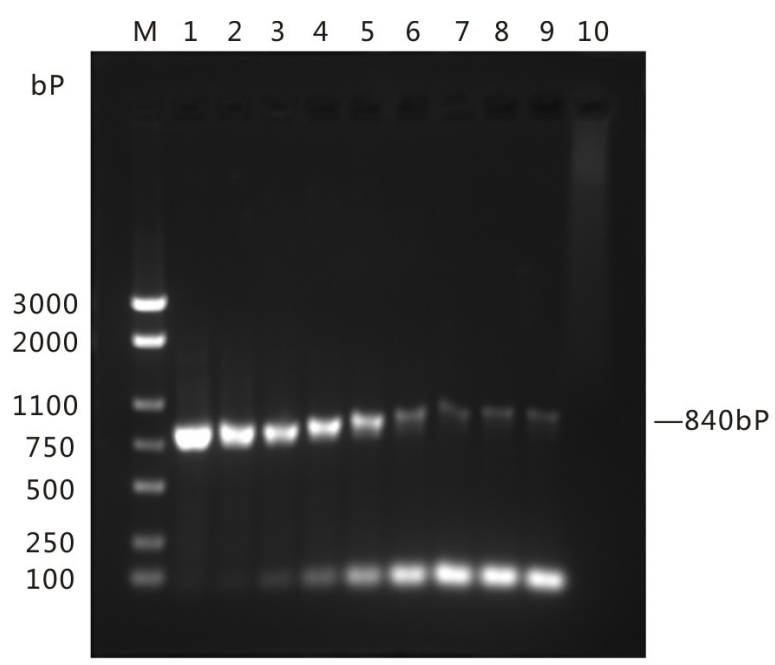

A

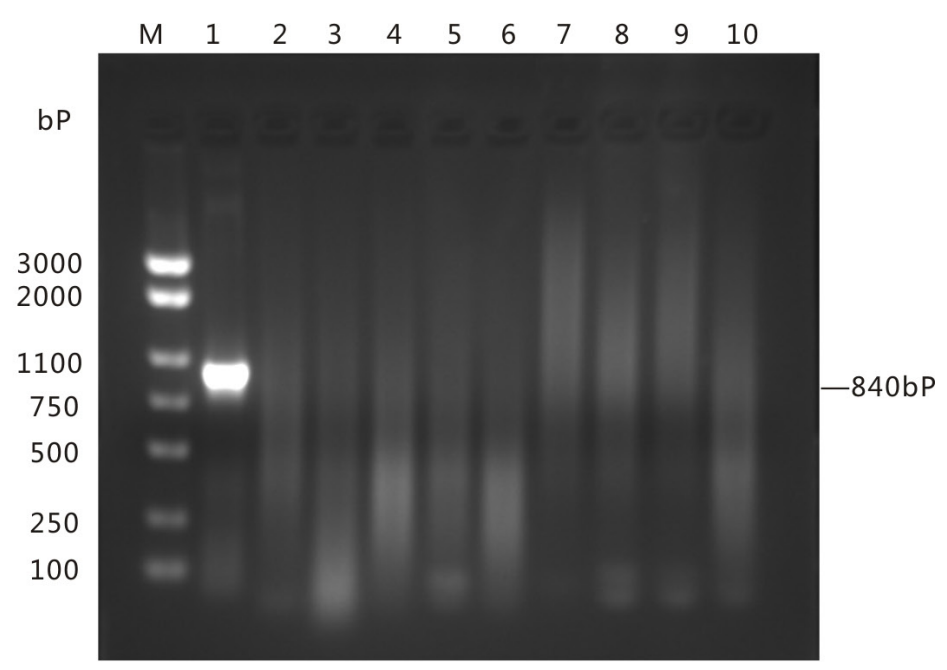

B

Figure 3. Detection of polymerase chain reaction (PCR) sensitivity and integration of plasmid pKS-asd into the host genomic DNA. Sensitivity of PCR detection for pKS-asd positive plasmid DNA in the host genomic DNA (A), lane 1-10: $10^{-1}, 10^{-2}, 10^{-3}, 10^{-4}, 10^{-5}, 10^{-6}, 10^{-7}, 10^{-8}, 10^{-9}, 10^{-10}$ dilution of pKS-asd plasmid, respectively, lane M: 100 bp ladder DNA Marker (3,000 bp); Results of plasmid pKS-asd integration into the host genomic DNA (B), lane 1: amplification of pKS-asd (positive control) for KS (KISS1 metastasis suppressor and hepatitis B surface antigen S) gene (840 bp), lanes 2-10: amplification of genome DNA from hypothalamus, testis, heart, liver, lung, spleen, kidney, muscle, and small intestine, respectively, of vaccinated ram lambs for KS gene; lane M: 100 bp ladder DNA Marker (3,000 bp). 
vertical area in Figure 1 shows that the inflexion of testis growth recovery could occur between week 14 and 22 after the primary immunization. This finding is a result of the sharp increase in serum testosterone and scrotal circumference in the vaccinated group, which could have resulted in the compensation of serum testosterone secretion and testis growth. Previous studies showed that several anti-GnRH-vaccines can decrease testosterone concentrations and testicular dimension in male animals, and serum progesterone concentrations and cyclic ovarian activity in female animals. However, the effects of the anti-GnRH-vaccines are reversible [28-30]. The current study showed that the effects of KISS1 gene immunocastration were also reversible in ram lambs.

We did not detect KS fusion fragment of KISS1 gene vaccine integrated in the genomic DNA of the host cell in nine different tissues in vaccinated ram lambs. This finding indicated that KISS1 gene vaccine did not integrate into the host cell genomic DNA of vaccinated ram lambs. The potential frequency of integration of plasmid pKS-asd into host genomic DNA was lower than the spontaneous number of mutations. This finding indicated that pKS-asd is genetically safe for use as immunocastration gene vaccine. Previous studies also showed that the gene vaccines did not integrate in vivo into the genomic DNA of host cells [16,31]. Therefore, these results demonstrate a lack of integration events for KISS1 gene immunocastration.

In conclusion, KISS1 gene immunocastration was reversible without integration to the host genome. Further studies should be conducted to investigate the effect of KISS1 gene vaccine in controlling fertility by the mating trials in rams and other pets. Other safety aspects such as long-term persistence and vertical transmission should also be further studied.

\section{CONFLICT OF INTEREST}

We certify that there is no conflict of interest with any financial organization regarding the material discussed in the manuscript.

\section{ACKNOWLEDGMENTS}

This work was financially supported the Fundamental Research Funds for the Central Universities (No. XDJK2016C018, No. SWU115066), the National Natural Science Foundation of China (No. 31772598), the China National Meat-type Sheep and Goat Industrial Technology System (No. CARS-38), Chongqing Research Program of Basic Research and Frontier Technology (No. cstc2015jcyjBX0002).

\section{REFERENCES}

1. Han X, Zhou Y, Zeng Y, et al. Effects of active immunization against GnRH versus surgical castration on hypothalamicpituitary function in boars. Theriogenology 2017;97:89-97.

2. Pérez-Linares C, Bolado-Sarabia L, Figueroa-Saavedra F, et al. Effect of immunocastration with Bopriva on carcass characteristics and meat quality of feedlot Holstein bulls. Meat Sci 2017;123:45-9.

3. Eisemann JD, O'Hare JR, Fagerstone KA. State-level approaches to managing the use of contraceptives in wildlife in the United States. J Zoo Wildl Med 2013;44:S47-51.

4. Gupta SK, Minhas V. Wildlife population management: are contraceptive vaccines a feasible proposition? Front Biosci (Schol Ed) 2017;9:357-74.

5. Goericke-Pesch S, Wehrend A, Georgiev P. Suppression of fertility in adult cats. Reprod Domest Anim 2014;49(Suppl 2):33-40.

6. Messager S, Chatzidaki EE, Ma D, et al. Kisspeptin directly stimulates gonadotropin-releasing hormone release via $\mathrm{G}$ protein-coupled receptor 54. Proc Natl Acad Sci USA 2005; 102:1761-6.

7. Skorupskaite K, George JT, Anderson RA. The kisspeptinGnRH pathway in human reproductive health and disease. Hum Reprod Update 2014;20:485-500.

8. Han Y, Liu G, Jiang X, et al. KISS1 can be used as a novel target for developing a DNA immunocastration vaccine in ram lambs. Vaccine 2015;33:777-82.

9. Martin T, Parker SE, Hedstrom R, et al. Plasmid DNA malaria vaccine: the potential for genomic integration after intramuscular injection. Hum Gene Ther 1999;10:759-68.

10.Zhao Y, Bao Y, Zhang L, et al. Biosafety of the plasmid pcDNA31E of Eimeria acervulina in chicken. Exp Parasitol 2013;133: 231-6.

11. Han L, Zhen YH, Liang AX, et al. Oral vaccination with inhibin DNA delivered using attenuated Salmonella choleraesuis for improving reproductive traits in mice. J Basic Microbiol 2014; 54:962-8.

12. Graham FL, van der Eb AJ. A new technique for the assay of infectivity of human adenovirus 5 DNA. Virology 1973;52: 456-67.

13. Wigler M, Pellicer A, Silverstein S, et al. DNA-mediated transfer of the adenine phosphoribosyltransferase locus into mammalian cells. Proc Natl Acad Sci USA 1979;76:1373-6.

14.Zhang F, Fang F, Chang H, et al. Comparison of protection against $\mathrm{H} 5 \mathrm{~N} 1$ influenza virus in mouse offspring provided by maternal vaccination with HA DNA and inactivated vaccine. Arch Virol 2013;158:1253-65.

15.Liang A, Riaz H, Dong F, et al. Evaluation of efficacy, biodistribution and safety of antibiotic-free plasmid encoding somatostatin genes delivered by attenuated Salmonella enterica serovar Choleraesuis. Vaccine 2014;32:1368-74.

16. Huang LY, Wang KY, Xiao D, et al. Safety and immunogenicity of an oral DNA vaccine encoding Sip of Streptococcus agalac- 
tiae from Nile tilapia Oreochromis niloticus delivered by live attenuated Salmonella typhimurium. Fish Shellfish Immunol 2014;38:34-41.

17. Khan MAH, Ogita K, Ferro VA, et al. Immunisation with a plasmid DNA vaccine encoding gonadotrophin releasing hormone (GnRH-I) and T-helper epitopes in saline suppresses rodent fertility. Vaccine 2008;26:1365-74.

18. Harstine BR, Maquivar M, Helser LA, et al. Effects of dietary energy on sexual maturation and sperm production in Holstein bulls. J Anim Sci 2015;93:2759-66.

19. Uliana SR, Affonso MH, Camargo EP, Floeter-Winter LM. Leishmania: genus identification based on a specific sequence of the 18S ribosomal RNA sequence. Exp Parasitol 1991;72: 157-63.

20. Caldara FR, Moi M, Dos Santos LS, et al. Carcass characteristics and qualitative attributes of pork from immunocastrated animals. Asian-Australas J Anim Sci 2013;26:1630-6.

21. Moore KL, Mullan BP, Dunshea FR. Boar taint, meat quality and fail rate in entire male pigs and male pigs immunized against gonadotrophin releasing factor as related to body weight and feeding regime. Meat Sci 2017;125:95-101.

22. Siel D, Vidal S, Sevilla R, et al. Effectiveness of an immunocastration vaccine formulation to reduce the gonadal function in female and male mice by Th1/Th2 immune response. Theriogenology 2016;86:1589-98.

23. Khan MAH, Ferro VA, Koyama S, et al. Immunisation of male mice with a plasmid DNA vaccine encoding gonadotrophin releasing hormone (GnRH-I) and T-helper epitopes suppresses fertility in vivo. Vaccine 2007;25:3544-53.

24. Yeung VP, Gieni RS, Umetsu DT, DeKruyff RH. Heat-killed
Listeria monocytogenes as an adjuvant converts established murine Th2-dominated immune responses into Th1-dominated responses. J Immunol 1998;161: 4146-52.

25. Vernot JP, Perez-Quintero LA, Perdomo-Arciniegas AM, Quijano S, Patarroyo ME. Herpesvirus saimiri immortalization of Aotus T lymphocytes specific for an immunogenically modified peptide of Plasmodium falciparum merozoite surface antigen 2. Immunol Cell Biol 2005;83:67-74.

26. Guo L, Chen J, Qiu Y, et al. Enhanced transcutaneous immunization via dissolving microneedle array loaded with liposome encapsulated antigen and adjuvant. Int J Pharm 2013;447:2230.

27. Qiu Y, Guo L, Zhang S, et al. DNA-based vaccination against hepatitis B virus using dissolving microneedle arrays adjuvanted by cationic liposomes and CpG ODN. Drug Deliv 2016;23:2391-8.

28. Dowsett KF, Tshewang U, Knott LM, Jackson AE, Trigg TE. Immunocastration of colts and immunospeying of fillies. Immunol Cell Biol 1993;71(Pt 5):501-8.

29. Schulman M, Botha AE, Muenscher SB, et al. Reversibility of the effects of $\mathrm{GnRH}$-vaccination used to suppress reproductive function in mares. Equine Vet J 2013;45:111-3.

30.Lugar DW, Rhoads ML, Clark-Deener SG, et al. Immunological castration temporarily reduces testis size and function without long-term effects on libido and sperm quality in boars. Animal 2017;11:643-9.

31. Wolff JA, Ludtke JJ, Acsadi G, Williams P, Jani A. Long-term persistence of plasmid DNA and foreign gene expression in mouse muscle. Hum Mol Genet 1992;1:363-9. 